\title{
Are Customers Satisfied with Service Quality in Malaysia Airports? Empirical Findings from Penang Airport
}

Ahmad Rizam bin Abdul Rahim, Zaherawati Zakaria, Nazmi @ Nazni Noordin, Mohd Zool Hilmie Mohamed Sawal

To Link this Article: http://dx.doi.org/10.6007/IJARBSS/v12-i1/12033

DOI:10.6007/IJARBSS/v12-i1/12033

Received: 06 November 2021, Revised: 12 December 2021, Accepted: 27 December 2021

Published Online: 19 January 2022

In-Text Citation: (Rahim et al., 2022)

To Cite this Article: Rahim, A. R. bin A., Zakaria, Z., Noordin, N. @ N., \& Sawal, M. Z. H. M. (2022). Are Customers Satisfied with Service Quality in Malaysia Airports? Empirical Findings from Penang Airport. International Journal of Academic Research in Business and Social Sciences, 12(1), 1417-1427.

Copyright: (c) 2022 The Author(s)

Published by Human Resource Management Academic Research Society (www.hrmars.com)

This article is published under the Creative Commons Attribution (CC BY 4.0) license. Anyone may reproduce, distribute, translate and create derivative works of this article (for both commercial and non0-commercial purposes), subject to full attribution to the original publication and authors. The full terms of this license may be seen at: http://creativecommons.org/licences/by/4.0/legalcode

Vol. 12, No. 1, 2022, Pg. $1417-1427$

Full Terms \& Conditions of access and use can be found at http://hrmars.com/index.php/pages/detail/publication-ethics 


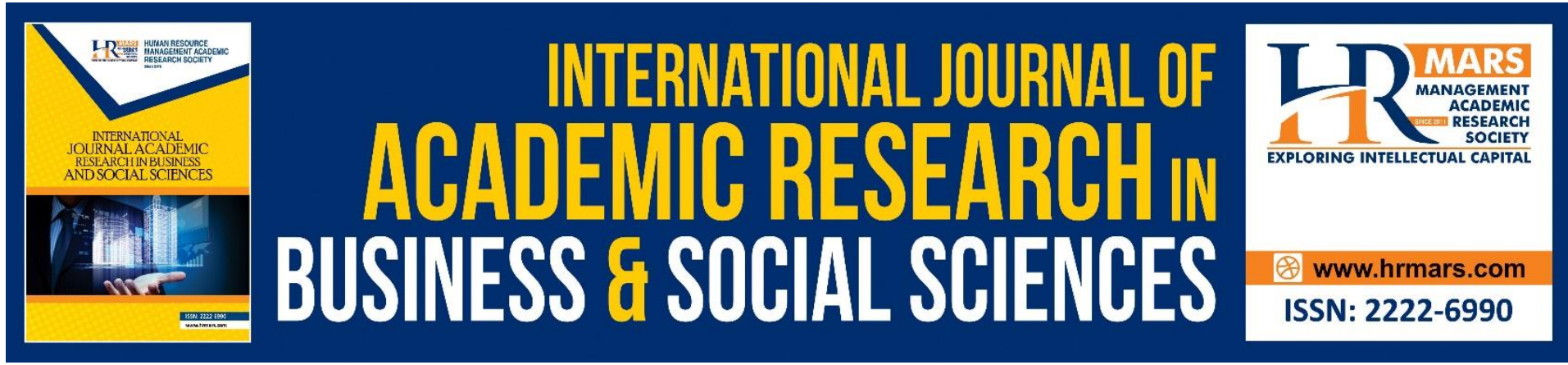

\title{
Are Customers Satisfied with Service Quality in Malaysia Airports? Empirical Findings from Penang Airport
}

\author{
Ahmad Rizam bin Abdul Rahim \\ Reflections, 1B-11-7, Persiaran Nuri, SP Setia, 11900, Bayan Lepas, Pulau Pinang \\ Email: ahmadrizam@gmail.com
}

Zaherawati Zakaria (Corresponding author)

Faculty of Administrative Science and Policy Studies, 08400 Merbok, Kedah

Email:zaherawati@uitm.edu.my

Nazmi@ Nazni Noordin

Faculty of Administrative Science and Policy Studies, 08400 Merbok, Kedah

Email:nazni@uitm.edu.my

Mohd Zool Hilmie Mohamed Sawal

Faculty of Information Management, 08400 Merbok, Kedah

Email: zoolhilmie@uitm.edu.my

\begin{abstract}
In order to measure the level of airport service, consumers can categorize their experiences into passenger and freight disposition, waiting areas, mobile facilities within the airport, auxiliary facilities, and accessible traffic equipment. If the service delivery having issues and not up to the expectation of customers, it can affect the business. The SERVQUAL model, which is test in this study, is the widely approach of measuring service quality in order to help service providers in identifying their strengths and weaknesses. This study uses the quantitative method through survey in order to know the extent of customers satisfies and how dimensions of SERVQUAL has relationship with customer satisfaction at Penang Airport. The findings show that customers are satisfies with the services given by the airport and dimension of assurance seems the strong relationship with customer satisfaction. In recommendation, the author hopes the airport management will increase more effective signage and wayfinding at Penang International Airport, as well as an understanding of the needs of passengers. In future research, perhaps more studies will unearth the service delivery from different aspect to assists management of the airport more transparent and down to earth entertaining the customers.
\end{abstract}

Keywords: Customer Satisfaction, Airport, Service Quality, Dimensions 


\section{Introduction}

There is little agreement in the marketing literature on the concept of service quality, which has led to disagreement about the best method for measuring service quality (Brady \& Cronin, 2001). Parasuraman et al (1985) created a conceptual model to measure service quality called SERVQUAL. Servqual was a method first discovered by Parasuraman, Zeithaml, and Berry in 1985. This method was used to allow airport operators to quickly identify passengers 'perceptions and expectations of the services they had donated. The quality of services provided to users is so difficult to measure, but Zeithaml, Parasuraman, and Berry (2003) formulate the dimensions of service quality to be used as a measuring tool to evaluate a service namely Tangibles, Reliability, Responsiveness, Assurance, and Empathy. Therefore, the reliability required by airport operators to adapt to the wants and needs of airport passengers. Based on the model proposed by Fodness \& Murray (2007), the authors conducted a study at O.R. Tambo International Airport (South Africa), where they investigated three areas of services provided by the airport, interaction, function and diversion. According to Brady and Cronin (2001), an airport is where airport service providers interact with customers to deliver a service.

The overall airport services experienced by customers can be classified into passenger and cargo disposition, waiting areas, moving facilities within the airport, additional facilities, and accessible traffic equipment to evaluate airport services. Airport service quality is categorized into convenience, check -in time, usability, employee well -being, information visibility, and security as conceptual systems to contribute to the activation of quality control (Chen et al., 2002). Liou et al (2011) emphasize that the trend towards a more passenger-oriented approach is being welcomed in today's highly competitive transportation market. Therefore, although it is necessary to take a holistic approach, integrating information from service quality, passenger satisfaction, complaint handling and service recovery, the passenger perspective must be the centre of strategic planning (Smith \& Grosbois, 2010). In Malaysia, MAVCOM (2018) received 11 complaints about airports involving KL International Airport (KLIA), KL International Airport 2 (KLIA2), and Sultan Abdul Aziz Shah Airport for the period 1 July to 31 December 2018. This is a decrease of $21.4 \%$ over the period July 1 to December 31 , 2017, when MAVCOM received 14 complaints about the airport. The complaints were mainly related to airport facilities, airport security and special assistance. Even though there are many studies conducted about service quality, little studies have been done about satisfaction of customer specifically about Malaysia's airport. Are there any similar scenarios happening at Penang airport? Do tangible factors, reliability, responsiveness, assurance and empathy contribute to the quality of service at Penang airport? Therefore, this study attempts to reveal the extent of service quality and what is the relationship with the 5 dimensions of SERVQUAL that affect passengers at Penang airport.

\section{Literature Review}

Quality services are crucial not only for customer loyalty, but also for the development of commercial and extra enterprises and the creation of lucrative businesses in today's world (Karim \& Chowdhury, 2014). The word "airport terminal" refers to a structure that houses a variety of vital amenities. The airport terminal, according to Price and Forrest (2016), is the airport's main passenger building, and it spans from the terminal's entrance to the screening checkpoint, including the foyer outside the screening checkpoint. According to Wattanacharoensil et al (2016), airport terminal services include security, customs, and immigration, as well as commercial and non-aviation facilities such as grocery stores, food 
and beverage areas, entertainment venues, and internet access. Nowadays, airports should place a great emphasis on enhancing service quality, or the level of perception of service provided to their clients (Pantouvakis \& Renzi, 2016). Passenger happiness is still a nebulous term. Given the continuously changing nature of the airport sector, airports should place a heavy emphasis on enhancing service quality, or the level of perception of services provided to customers (Pantouvakis \& Renzi, 2016). The quality of airport services can have an indirect impact on the tourism industry and related commercial operations, as satisfied travellers are more likely to return to the airport and promote it to other potential travellers (Park \& Jung, 2011).

Gures et al (2014) define tangible as the physical appearance of employees, facilities, equipment, personnel, and communication materials utilised to offer service to an organisation. All of these give the service a physical appearance. Tangibility, according to Parasuraman et al (1985), is described as the appearance of physical offices, equipment, work force, and correspondence materials. Customers do not always complain about their experience as impersonal service when employees overlook or mistreat them. Rather, the customer will never return, which is something that no business wants to happen. The capacity to perform the guaranteed benefit reliably and accurately is characterised as reliability (Donnelly et al., 2012). If a business is offering good service, it and its employees should be prepared to answer questions from customers regarding the products and services it offers (Ojo, 2010). According to Aftab et al (2016), one of the most essential consumer expectations is prompt responses to requests. As a result, simply because these are fundamental issues, they should not be postponed or neglected. This factor has consistently been found to be the most important indicator of service quality perceptions (Punjaisri et al., 2008). According to Ennew et al (2013), reliability is defined as the ability to accomplish and perform the required service for customers reliably, accurately, and as promised, as well as the ability to treat customer complaints. The most essential criteria in keeping clients in banking services, according to Peng and Moghavvemi (2015), are accuracy in processing orders, maintaining precise records and quotations, accuracy in billing, and performing promised services. Workers' preparedness or willingness to provide instant benefit or reaction to a customer request is defined as responsiveness.

Provide prompt service and a willingness to assist consumers (Donnelly, Simmons, Armstrong \& Fearne (2012). Customers value prompt service, which is something that competent service providers should be aware of (Ahmed et al., 2010). Exit and voice (communicating user requests) have been identified as recovery processes for making companies responsive in the literature (Peng and Moghavvemi, 2015). Assurance is defined as the kindness, competence, credibility, and security provided by a company's personnel to its customers. Parasuraman et al. (1985) interpreted (AS) as information on workers' cordiality and ability to inspire confidence and trust. Customers will desire to do business with a company if its representatives deliver real and caring service (Angelova \& Zekiri, 2011). The importance and perceived performance of the assurance service quality attribute differs depending on the study. In general, private patients from Malaysian hospitals had low expectations for the assurance aspects, particularly the item "capacity to deal with problems." For all of the items, their perceptions score for the performance exceeded their expectations (Sohail, 2003). Empathy can be defined as the company's concern and personalised attention to its clients (Armstrong, 2012). Empathy is a factor that reflects customer and staff interactions (Donnelly et al., 2012). According to Gbadeyan and Gbonda (2011), attracting clients through caring is a crucial determinant, as is giving variety in the features of service items that would meet 
their wants and needs in the marketplace. Customers must believe that the entity delivering services prioritises them.

\section{Research Methodology}

This study used the method of quantitative through survey in order to answer the research objectives. Cross sectional survey used to get the information from the respondent which are 130 sample size taken by the researchers. The purposive sampling technique is used while getting the data from the fieldwork. This study used the method of quantitative survey in order to answer the research objectives. A cross sectional survey used to get information from the respondents which are 130 sample size taken by the researchers from October 2019 till March 2020. The purposive sampling technique is used while getting the data from the fieldwork. During data collection, the self-administered Questionnaire (SAQ) used by the researchers while 3 weeks needed to collect the data among the customers at Penang Airport. The descriptive analysis was followed with correlation in order to know the relationship between customer satisfaction with 5 dimensions of SERVQUAL.

\section{Findings and Discussions Demographic profile}

130 respondents answered all the questionnaires distributed, most of which were female, and $58.5 \%$ and $41.5 \%$ were male. As a result, the majority of respondents between the ages of 21 and 30 were 40.0, 34.6 between the ages of 31 and 40, 20.8 between the ages of 41 and 50 , and a small number of respondents over the age of $51.4 .6 \%$. Regarding the status of marriage, $46.9 \%$ of the surveyed people are single, while $43.8 \%$ are married and only $9.2 \%$ are divorced. Regarding varieties, the percentage of Malays is the highest at $39.2 \%$, followed by Chinese at $30.0 \%$, India at $19.2 \%$, and others at $11.5 \%$. In addition, secondary school (SPM) has the highest percentage of education level at $29.2 \%$, followed by diplomas at $26.2 \%$, graduations at $17.7 \%$, STPM at $16.2 \%$, and other 50 s with the lowest educational background at 10.8 . It was shown that there is. \%. Monthly income was shown to be highest between $\mathrm{RM} 2501$ and $\mathrm{RM} 3500$ at $42.3 \%$ and less than RM 2500 at $40.0 \%$. The minority of respondents with incomes from RM3501 to RM4.500 are 11.5\%, with the lowest proportion of $6.2 \%$ coming from incomes above RM4501. Finally, the results show that most respondents work in the public sector at the highest rate of $41.5 \%$, while the second highest at $32.3 \%$ is in the private sector and others at $13.8 \%$. The lowest percentage was shown to be $12.3 \%$. Selfemployed.

\section{Analysis of Findings}

Based on the results, the researchers used descriptive analysis to determine the extent of quality of service provided by passengers at Penang Airport. There are four questions that represent dependent variables. Each question has different answer options depending on the respondent's experience and circumstances and consists of 5 Likert scales: very bad, bad, average, good, and excellent. The total sample (N) was 130 respondents in all the statements tested. From the first statement, "I am satisfied with the quality" with an average value of 3.7846. The minimum answer is 1.00 and the maximum answer is 5.00. Standard deviation of The question is 0.98031 . Therefore, respondents give very poor and excellent answers to show how satisfied they are with the quality of Penang Airport. For the second statement, "I'm happy with the work I've done," the minimum answer is 3.00 , the maximum answer is 5.00 , and the standard deviation is 0.70778 . With an average of 4.0538 . The researchers found 
that most respondents were satisfied with the service provided. First, in the third statement, "Quality of service meets my expectations," the average is 3.4846 , followed by a minimum answer of 1.00 and a maximum answer of 5.00. The standard deviation is 1.01336. The average value of the last statement "I am satisfied with all the equipment provided" is 4.2231. The minimum answer is 2.00 , the maximum answer is 5.00 and the standard deviation is 0.63813 . This shows that respondents respond very well to good and minimal bad ratings. Overall, the results obtained from the descriptive analysis are that the quality of service had a positive impact on passenger satisfaction, which was an important antecedent to passenger loyalty at Penang Airport.

Table 1.1: Correlation statistics between tangibility and service quality at Penang airport

\begin{tabular}{|l|l|l|l|}
\hline \multicolumn{3}{|c|}{ Correlations } \\
\hline \multirow{4}{*}{ Service Quality } & Pearson Correlation & \multicolumn{1}{|c|}{ Service Quality } & \multicolumn{1}{|c|}{ Tangibility } \\
\cline { 2 - 4 } & Sig. (2-tailed) & 1 & $.382^{* *}$ \\
\cline { 2 - 4 } & $\mathrm{N}$ & 130 & .000 \\
\hline \multirow{3}{*}{ Tangibility } & Pearson Correlation & $.382^{* *}$ & 130 \\
\cline { 2 - 4 } & Sig. (2-tailed) & .000 & 1 \\
\cline { 2 - 4 } & $\mathrm{N}$ & 130 & 130 \\
\hline **. Correlation is significant at the 0.01 level (2-tailed). & \\
\hline
\end{tabular}

Based on the results obtained in Table 1.1, the correlation between passenger tangibility and quality of service at Penang Airport is $r=0.382$. and the significance relationship with $p<0.05$, which is $p=0.00$ and value $r=0.382$. This means that there is a significant relationship and both variables are reasonably correlated. The alternate hypothesis $\left(H_{a}\right)$ is accepted from the results as the analysis shows that there is a relationship between the tangibility of Penang Airport and the quality of service. Therefore, the results of the correlation show that tangibility is one of the factors contributing to the quality of service of passengers at Penang Airport. It also reflects the study made by by Santos (2012) which show there is a positive relationship between tangibility and quality. Therefore, service providers may choose to focus on making the service more specific and thereby influencing the expectations or experience of the service. 
Table 1.2: Correlation statistics between reliability and service quality at Penang airport

\begin{tabular}{|c|c|c|c|}
\hline \multicolumn{4}{|c|}{ Correlations } \\
\hline & & Service Quality & Reliability \\
\hline \multirow[t]{3}{*}{ Service Quality } & Pearson Correlation & 1 & $.449^{* *}$ \\
\hline & Sig. (2-tailed) & & .000 \\
\hline & $N$ & 130 & 130 \\
\hline \multirow[t]{3}{*}{ Reliability } & Pearson Correlation & $.449^{* *}$ & 1 \\
\hline & Sig. (2-tailed) & .000 & \\
\hline & $N$ & 130 & 130 \\
\hline
\end{tabular}

Table 1.2 shows the result of the quality of service for passengers at Penang Airport is $r=$ 0.449 . The result is significant with $p<0.05$, which is $p=0.00$ and the value of $r=0.449$ has a significant relationship. From the results, the alternate hypothesis $\left(H_{a}\right)$ is accepted. It shows a relationship between the reliability and quality of service at Penang Airport. Therefore, it shows that reliability is one of the factors of quality of service in Penang airport. In a study by Okumuş and Asil (2007), reliable behavior of staff and ability to solve problems while driving and the ability to provide passengers is a key of customer satisfy.

Table 1.3: Correlation statistics between responsiveness and service quality at Penang airport

\begin{tabular}{|c|c|c|c|}
\hline \multicolumn{4}{|c|}{ Correlations } \\
\hline & & Service Quality & Responsiveness \\
\hline \multirow[t]{3}{*}{ Service Quality } & Pearson Correlation & 1 & $.632^{* *}$ \\
\hline & Sig. (2-tailed) & & .000 \\
\hline & $N$ & 130 & 130 \\
\hline \multirow[t]{3}{*}{ Responsiveness } & Pearson Correlation & $.632^{* *}$ & 1 \\
\hline & Sig. (2-tailed) & .000 & \\
\hline & $N$ & 130 & 130 \\
\hline
\end{tabular}

Based on the results shown in Table 1.3, the responsiveness correlation with the quality of service for passengers at Penang Airport is $r=0.632$. The result is significant between both variables where the significant, $p<0.05$, which is $p=0.00$ and value of $r=0.632$. This means that there is a significant relationship between both variables. From the results, the alternate hypothesis $\left(\mathrm{H}_{\mathrm{a}}\right)$ is accepted. It shows a relationship between responsiveness and quality of service at Penang Airport. Therefore, it shows that responsiveness contributes to one of the factors of quality of service at Penang Airport. As Chinunda (2011) explain the negative constant availability gap for staff to support passengers. Overall, passengers are expected greater efforts to enable customer service staff to meet the needs of passengers. 
Table 1.4: Correlation statistics between assurance and service quality at Penang airport

\begin{tabular}{|l|l|l|l|}
\hline \multicolumn{3}{|c|}{ Correlations } \\
\hline \multirow{3}{*}{ Service Quality } & Pearson Correlation & \multicolumn{1}{|c|}{ Service Quality } & \multicolumn{1}{|c|}{ Assurance } \\
\cline { 2 - 4 } & Sig. (2-tailed) & & $.801^{* *}$ \\
\cline { 2 - 4 } & N & .000 \\
\hline \multirow{3}{*}{ Assurance } & Pearson Correlation & $.801^{* *}$ & 130 \\
\cline { 2 - 4 } & Sig. (2-tailed) & .000 & 1 \\
\cline { 2 - 4 } & N & 130 & 130 \\
\hline$* *$ Correlation is significant at the 0.01 level (2-tailed). \\
\hline
\end{tabular}

Based on the results obtained as shown in Table 1.4, the correlation between assurance and service quality among passengers at Penang airport is where the significant, $p<0.05$, which is $p=0.00$ and $r=0.801$., which implies that there is a relationship between empathy as measurement scale for service quality. This means that there is a significant relationship and both variables were at strong level. As a result, empathy is an influencing factor that contributes to service quality among passengers at Penang airport. The alternate hypothesis $\left(\mathrm{H}_{\mathrm{a}}\right)$ is accepted because the analysis shows there is a correlation between empathy and service quality at Penang airport. Therefore, it shows that empathy has become one of the factors contributing to the quality of service at Penang Airport. As Sweeney \& Swait (2008), points out, empathy is an ability that goes beyond the capabilities of employees and perform tasks efficiently.

Table 1.5: Correlation statistics between empathy and service quality at Penang airport

\begin{tabular}{|c|c|c|c|}
\hline \multicolumn{4}{|c|}{ Correlations } \\
\hline & & Service Quality & Empathy \\
\hline \multirow[t]{3}{*}{ Service Quality } & Pearson Correlation & 1 & $.576^{* *}$ \\
\hline & Sig. (2-tailed) & & .000 \\
\hline & $N$ & 130 & 130 \\
\hline \multirow[t]{3}{*}{ Empathy } & Pearson Correlation & $.576^{* *}$ & 1 \\
\hline & Sig. (2-tailed) & .000 & \\
\hline & $N$ & 130 & 130 \\
\hline
\end{tabular}

Based on the results obtained as per Table 1.5, the correlation between assurance and the quality of service among passengers at Penang airport is $r=0.576$. The results show there is significantly related to service quality with a $P$ value more than 0.05 , which implies that there is the relationship between empathy and service quality. This means that there is a significant relationship and both variables. From the result, empathy has an influential factor that contributes to the quality of service among passengers at Penang airport. The alternate hypothesis $\left(\mathrm{H}_{\mathrm{a}}\right)$ was accepted because the analysis showed that there was a correlation between empathy and quality of service at Penang airport. Thus, it shows that empathy has 
become one of the factors contributing towards the quality of service at Penang airport. As noted by Sweeney \& Swait (2008), empathy is a skill that exceeds an employee's ability to perform their duties efficiently. He further suggested that it may require some training to apply this ability to be empathetic to customers.

\section{Discussions and Recommendations}

The researchers made several recommendations based on the outcomes such as better signage and wayfinding, better knowledge of passengers' demands and an e mphasis on cleanliness and lavatory upgrades. In future, it should focus on a broader spectrum of characteristics that contribute to service quality, using the number of passengers at Penang airport as a sample size. Finally, the researcher recommends employing a combination of qualitative and quantitative methodologies, such as surveys and interviews to better understand and explain respondents' perspectives. Contribution from this study perhaps can helps the Airlines better performance and frontline employees motivate to provide the best customer satisfaction. Airlines management must devise all strategy and program to meet these key areas of operation.

\section{Conclusion}

Finally, the research answered all of the objectives by making the researchers understood of the extent of service quality affects customers at Penang Airport and determining the dimensions that influence its service. A total of 130 people were chosen from the Penang airport to complete the researcher's questionnaires. All of the variables in the study that examined the relationship between independent variables and dependent variables such as tangibility, reliability, responsiveness, assurance and empathy. According to the findings, two independent factors, tangibility and dependability, have a moderate association with the dependent variable. The independent variables of responsiveness, assurance and empathy have a strong association with the dependent variable. As a result, the data revealed that there are elements that contribute to the quality of service provided to customers at Penang Airport. The precision of direction signs and terminology must also be improved. In future studies, the study should take into account additional criteria including competence, civility and security.

\section{References}

Aftab, J., Sarwar, H., Sultan, Q. U. A., \& Qadeer, M. (2016). Importance of service quality in customer satisfaction (A study on fast food restaurants). Entrepreneurship and innovation management journal, 4(4), 161-171.

Ahmed, I., Nawaz, M. M., Usman, A., Shaukat, M. Z., \& Ahmed, N. (2010). A mediation of customer satisfaction relationship between service quality and repurchase intentions for the telecom sector in Pakistan: A case study of university students. African journal of business management, 4(16), 3457-3462.

Angelova, B., \& Zekiri, J. (2011). Measuring customer satisfaction with service quality using American Customer Satisfaction Model (ACSI Model). International journal of academic research in business and social sciences, 1(3), 232.

Akinyosoye-Gbonda, O. O. (2011). Customers 'preference for E-Banking Services: A Case Study of Selected Banks in Sierra Leone. Australian journal of business and Management research, 1(4), 108-116. 
Brady, M. K., and Cronin, J. J. Jr. (2001), "Some new thoughts on conceptualizing perceived service quality: a hierarchical approach", Journal of Marketing, Vol. 65, July, pp. 34- 49.

Chen, J. K., Taipale, J., Cooper, M. K., \& Beachy, P. A. (2002). Inhibition of Hedgehog signaling by direct binding of cyclopamine to Smoothened. Genes \& development, 16(21), 27432748.

Chinunda, E. D. (2011). Practical Insights on Customer Service. Adonis \& Abbey Publishers Ltd.

Cowper-Smith, A., \& de Grosbois, D. (2011). The adoption of corporate social responsibility practices in the airline industry. Journal of Sustainable Tourism, 19(1), 59-77.

Donnelly, C., Simmons, G., Armstrong, G., \& Fearne, A. (2012). Marketing planning and digital customer loyalty data in small business. Marketing Intelligence \& Planning.

Ennew, C., Waite, N., \& Waite, R. (2013). Financial services marketing: An international guide to principles and practice. Routledge.

Fodness, D., \& Murray, B. (2007). Passengers' expectations of airport service quality. Journal of Services Marketing.

Forrest, J., \& Price, J. (2016). Practical aviation security: predicting and preventing future threats.

Gures, N., Arslan, S., \& Tun, S. Y. (2014). Customer expectation, satisfaction and loyalty relationship in Turkish airline industry. International Journal of Marketing Studies, 6(1), 66.

Karim, R., \& Chowdhury, T. (2014). Customer satisfaction on service quality in private commercial banking sector in Bangladesh. British Journal of Marketing Studies, 2(2), 111.

Kang, Y. S., Park, H. J., \& Jung, J. W. (2011). A study on the effects of the selection attributes of Korean restaurant menu on customer satisfaction and revisit intention. Culinary science and hospitality research, 17(2), 1-17.

Liou, J. J., Tsai, C. Y., Lin, R. H., \& Tzeng, G. H. (2011). A modified VIKOR multiple-criteria decision method for improving domestic airlines service quality. Journal of Air Transport Management, 17(2), 57-61.

Ojo, O. (2010). The relationship between service quality and customer satisfaction in the telecommunication industry: Evidence from Nigeria. BRAND. Broad Research in Accounting, Negotiation, and Distribution, 1(1), 88-100.

Okumus, A., \& Asil, H. (2007). Examining The Effects of Perceived Service Quality On Airline Passengers 'overall Satisfaction Level. An International Journal.

Pantouvakis, A., \& Renzi, M. F. (2016). Exploring different nationality perceptions of airport service quality. Journal of air transport management, 52, 90-98.

Parasuraman, A., Zeithaml, V. A., and Berry, L. L. (1985), "A conceptual model of service quality and its implication", Journal of Marketing, Vol. 49, Fall, pp. 41-50.

Parasuraman, A., Zeithaml, V. A., \& Berry, L. L. (1985). A conceptual model of service quality and its implications for future research. Journal of marketing, 49(4), 41-50.

Peng, L. S., \& Moghavvemi, S. (2015). The dimension of service quality and its impact on customer satisfaction, trust, and loyalty: A case of Malaysian banks. Asian Journal of Business and Accounting, 8(2).

Punjaisri, K., Wilson, A., \& Evanschitzky, H. (2008). Exploring the influences of internal branding on employees' brand promise delivery: implications for strengthening customer-brand relationships. Journal of Relationship Marketing, 7(4), 407-424.

Santos, F. M. (2012). A positive theory of social entrepreneurship. Journal of business ethics, 111(3), 335-351. 
Sohail, M. S. (2003). Service quality in hospitals: more favorable than you might think. Managing Service Quality:

Sweeney, J., \& Swait, J. (2008). The effects of brand credibility on customer loyalty. Journal of retailing and consumer services, 15(3), 179-193.

Wattanacharoensil, W., Schuckert, M., \& Graham, A. (2016). An airport experience framework from a tourism perspective. Transport reviews, 36(3), 318-340.

Zeithaml, V. A., Parasuraman, A., Berry, L. L. (2003). SERVQUAL: a multipleitem scale for measuring consumer perceptions of service quality. J Retailing. 1998;64(1):12-40. 